\title{
Assessing and Delineation of Groundwater Recharge Areas in Coastal Arid Area in Tunisia Using GIS, Remote Sensing Techniques and Self- organizing Map
}

Bilel Abdelkarim ( $\square$ abdelbilel92@gmail.com )

University of Gabes: Universite de Gabes

Faten Telahigue

University of Gabes: Universite de Gabes

Belgacem Agoubi

University of Gabes: Universite de Gabes

\section{Research Article}

Keywords: potential recharge, self-organizing maps, arid zones, GIS approach, Gabes

Posted Date: January 7th, 2022

DOI: https://doi.org/10.21203/rs.3.rs-1160687/v1

License: (c) (1) This work is licensed under a Creative Commons Attribution 4.0 International License.

Read Full License 


\title{
Assessing and delineation of groundwater recharge areas in coastal arid
}

\section{area in Tunisia using GIS, Remote sensing techniques and Self-organizing}

map

\author{
Bilel Abdelkarim ${ }^{1}$, Faten Telahigue ${ }^{2}$, Belgacem Agoubi ${ }^{3}$ \\ 1,2,3 Institut Supérieur des Sciences et Techniques des Eaux de Gabès, Université de Gabès, \\ Gabès, Tunisia. LR: Applied Hydro-Sciences Laboratory research \\ Campus universitaire, 6072 Zrig, Gabes, Tunisia \\ *Corresponding author: Bilel Abdelkarim \\ E-mail:abdelbilel92@gmail.com
}

\begin{abstract}
In Gabès region (southeastern Tunisia), given the semi-arid to arid climate conditions, groundwater is an essential resource to supply the growth needs of the socio-economic development. To ensure sustainable development and preserve-water resources, a careful estimation of the present day recharge amount and the delineation of the potential zones of rainfall precipitation are of required for an accurate evaluation of regional water balance. In this context, this study aims to a preliminary assessment of groundwater recharge in Gabes basin in regard to the delineation of the potential recharge areas of phreatic aquifers. Thus, a geological and hydrogeological collected database coupled with remote sensing techniques (RST) were
\end{abstract}


used for the determination of the lateral variation of recharging zone, Treatment by ArcGIS and Matlab softwares and Kohonen self-organizing maps (K-SOM) approaches.

The obtained results indicate that five recharge potential areas have been identified and classified as $27 \%$ very low, $23 \%$ low, $40 \%$ moderate recharge, $7 \%$ good and $3 \%$ very good potential recharge located principally on southern part of the study region . This distribution is controlled principally by the geomorphological, geologic, and hydrogeologic features of the region . Reasonable management strategies based on a perennial exploitation of these low renewable resources are required to optimize the water dependent socio-economic development. The estimated groundwater potential recharge of Gabès aquifer system using KSOM and RST is of $11.4 \mathrm{Mm}^{3} \cdot \mathrm{y}^{-1}$. This recharging rate is very low it present $7 \%$ of the total rain, thus it must be ameliorated. K-SOM and RST approach is a useful method for groundwater potential recharge mapping and is a helpful of wells establishment and groundwater sustainable management.an isotopic analyses is recommended to ameliorate the decision maker to establish the adequate strategy.

Key words: potential recharge, self-organizing maps, arid zones, GIS approach, Gabes.

\section{Introduction}

Groundwater is the lifeblood of arid and semi-arid areas regarding to the lack of surface water and the rain scarcity. The limited fresh groundwater resources are continuously supplied to meet the growing demands of expansion economic activities and growing population. These deep confined and semi-confined aquifers, generally low renewable under present day climate conditions, have an important impact on ecosystems, well-being, societal growth and economic development (Hamed et al 2018, Parkinson et al 2020, Agoubi 2021). Under the combined effect 
of socio- economic conditions, climate variability and emerging consumption patterns, world water use has been increasing annually by about $1 \%$ since the 1980s (UNESCO, 2019) and global water demand is expected to continue increasing to meet domestic, agricultural and industrial needs.

The excessive exploitation of groundwater resources has led to many environmental issues challenging the sustainable use of these reservoirs (Kulmatov et al 2020, Pool et al 2021). Water withdrawal, aquifer decompression, water quality salinization and chemical evolution, pollution, are the commonly observed problems in many water-deficit regions, especially in developing countries, for example in Algeria(Bouderbala et al 2019), in Iraq (Awadh et al 2021) and in Australia(Akbari et al 2020).A reasonable management of these limited highly solicited resources is required. The adopted strategies may rely on a systematic monitoring of water quality and quantity evolution in the light of the available freshwater amount related to aquifer characteristics and the local and regional geological and hydrogeological context (Gude et al 2018, Nadiri et al 2019).Identifying and protecting potential groundwater recharge areas, and adopting proactive solutions to preserve the collected surface water volume, are the most feasible low expensive, and easy to implant remediation actions(Nadiri et al 2019). Indeed, potential recharge areas delineation is of paramount importance for aquifers management discussed by zones has been a subject of several works under different weather features and socio-economic conditions (Lee and Jones-Lee 1999; Mishra et al. 2010; Najib et al. 2018; Singh et al., 2019; Dar et al. 2020; Balamurugan et al., 2017; Yahyaoui et al. 2021). These studies confirmed that potential groundwater area mapping is not trivial task due to the large parameters number influencing the recharge process. In fact, groundwater recharge estimation is governed by several factors such as geology, precipitation and geomorphology (yeh et al 2016, Suissi et al 2018, Yahyaoui et al 2021).These works have, furthermore, adopted various methods based on geographic information system (GIS) and remote sensing techniques among 
other techniques to assess and classify potential recharge areas (yeh et al 2016, Nadiri et al 2019). The remote sensing techniques to assess groundwater potential recharge zone are used in several study all over the world; as example in India case study (Arulbalaji et al. 2019, Singh et al. 2019), in New Zealand (Dar et al. 2020). Yahyaoui et al., (2021) developed the groundwater potential recharge Index (GPRI) to identify potential recharge areas and to assess groundwater recharge in Ghomrassen region in Tunisia. In other side ,many others techniques have been used digital data processing and artificial intelligence techniques such as artificial neural network (ANN), random forest model (RFM), tree analysis model (TDM) and linear and logistic regression (LLR) in several works such as, Lee and Jones Lee (1999), Portaji and Borjasimi (2014) and Golkarian and Rahmaty (2018).The development of informational data processing technologies contributed rapidly to the use of digital methods which are becoming more available and commonly used for useful to hydrogeological researchers. This new techniques have contributed to the adoption of digital applications and to the improvement of scientific results qualities. Among the various tools that may be used for water resources mapping, the Kohonen self-organizing maps (K-SOM) (Kohonen 1982) constitutes a useful approach that consist to result the hydrogeology and hydrology problems by classifying the environmental and climate data. This mothed has been used in numerous study such as in ground water salinization and mixing (Agoubi et al 2018), water quality index (Tison et al. 2004; Kangur et al.2007).However, despite the important potential performance of this approach especially if it is coupled with supervised learning machine techniques, the K-SOM is still limited for recharge zones mapping (Kangur et al., 2007; Hsu and Li, 2010; Agoubi, 2018), and produced some very useful results. Various studies have evaluated groundwater recharge mapping in Tunisia by assigning of remote sensing tools to identify the pentantial recharge zones (Suissi et al 2018, Yahyaoui et al 2021), but there is no study in the literature that applies a K-SOM method based in remote sensing tool in that context. Thus, the objective 
of this work is to develop an approach for the delineation of potential groundwater recharge areas in which K-SOM techniques were combined to remote sensing techniques based on Shuttle Topography Mission (SRTM) data. A geological and hydrogeological database will be implemented to create a potential groundwater recharge map. Thus the main aims of the estimation of groundwater recharge were :(1) characterize the recharge area in the study region ;(2) discuss the adequate strategy used to valorize the most of groundwater recharging.

\section{Study area}

This study is carried out in the Gabès region, southeastern Tunisia (Fig. 1). This area is characterized by a Mediterranean climate in the coastal area with an annual average of 200 mm.year ${ }^{-1}$, whereas the western part is affected by an arid climate, dry and hot in the summer and wet and cool in the winter, with an annual precipitations do not exceed 150 mm.year ${ }^{-1}$ (Ben Alaya et al., 2013; Agoubi, 2018). Gabès region is characterized by no perennial rivers; however, heavy storms can create surface runoff, which is discharged via wadis such as Oued El Akarit, Oued jir and Oued El Hamma (Ben Alaya et al 2013, Agoubi et al 2018).

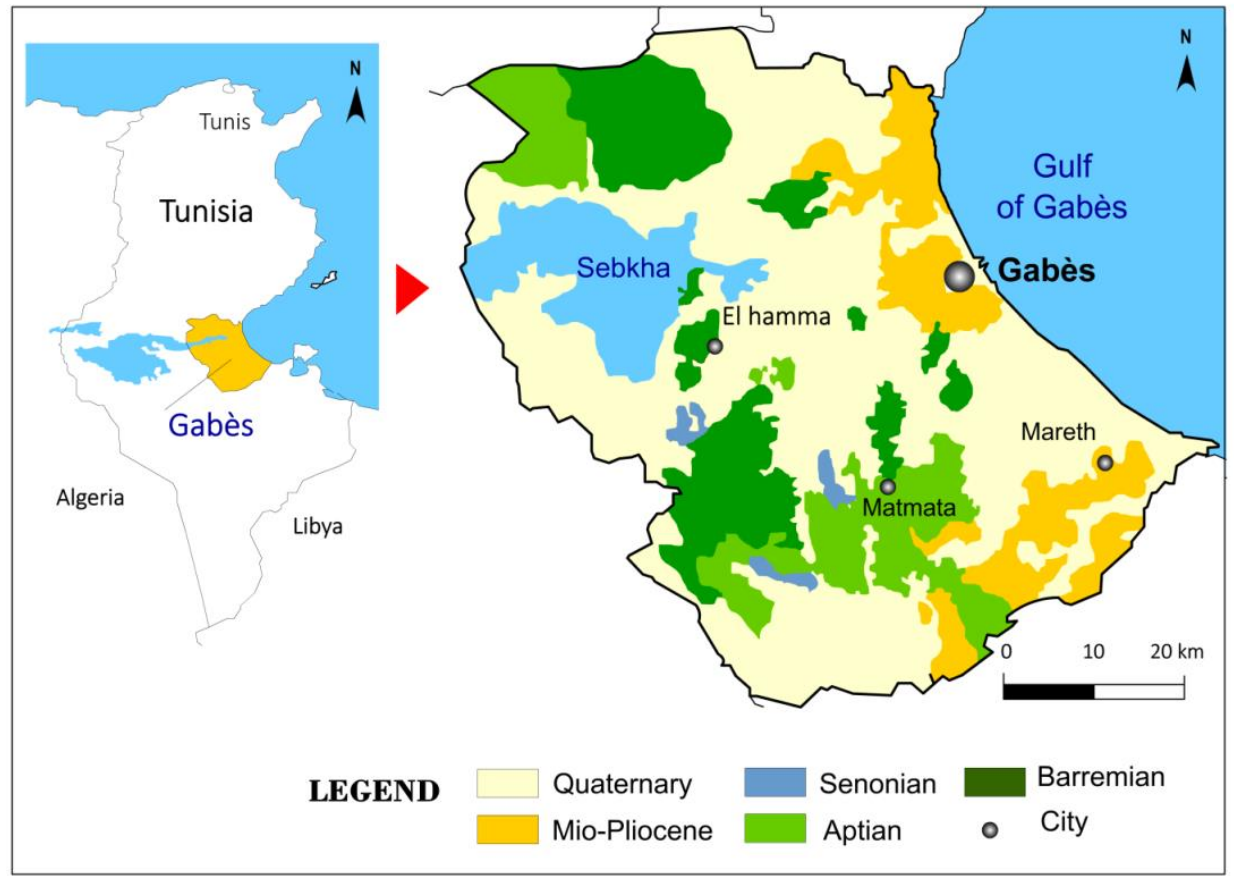

Fig.1 Location map and geological settings of study area 


\section{Geological setting}

The studied region is located in the eastern boundary of the Tunisian meridional Atlas. From a geological point of view, the study area characterized by the exposure of cretaceous and quaternary layers in surface (fig. 1). Tectonically, the study area constitutes a transition zone between the Dahar plateau from south-western and the jeffara-platform from the coastal zone. Furthermore, it characterized by the presence of salt depressions (Fejij chotts) (Zargouni 1985; Bouaziz et al. 2002).in addition ,the tectonic features present a multidirectional faults ; E-W normal Chotts fault, NW-SE Gafsa made a horsts and graben (Mamou 1990,Zouaghi et al. 2011). Due to these tectonic deformation, the permo-trassic substratum is brought up to very near the soil surface. The layers slant in the direction of the Mediterranean and get thicker elsewhere (Bouaziz, 1995). In the study area, Cretaceous formations were composed by Turonian and Albian. Thereby, the Barremian, is formed by gypsums, clay and anhydrite (Ben Hammouda et al., 2013). Whereas, the Albian is represented by dolomite, limestone and marl. The Turonian crops out southeastern part, and is composed of dolomite. The Mio-Pliocene is represented by gypsum, clays and sands. Finally, the Quaternary covers the region by clays with a crust of gypsum (Fig. 2).

\section{Hydrogeological setting}

In the Mediterranean coastal area of study area, the hydrogeological system of the area is made of different aquifers systems. According to the lateral variation and the tectonic accident, those aquifers are interconnected (lateral and vertical).in addition, the deferent reservoirs which are exploited in Gabes region are logged in the quaternary alluvium and in the cretaceous deposit.

The shallow aquifer is hosted in the sandy clays of Mio-Pliocene deposits, whereas the Senonian is composed by two stratigraphic units represented by limestone and marly limestone 
units (Sahli et al., 2013). In the continental western part of study area, the main aquifers were

137 logged in the cretaceous deposits such as the thermal continental intercalary and the jeffara aquifer (fig.2). The Senonian aquifer, hosted limestone and thermal continental intercalary (CI)

140 In other hand, the jeffara aquifers was formed in the upper cretaceous formations (Makni et al 141 2012, Agoubi et al 2018).those aquifers faced a dropdown in the Piezometric level due to the

142 low recharge process and the overexploitation of those resources in industry agriculture and 143 human activities(ben Hammouda et al 2013, ben Mahmoud 2015).

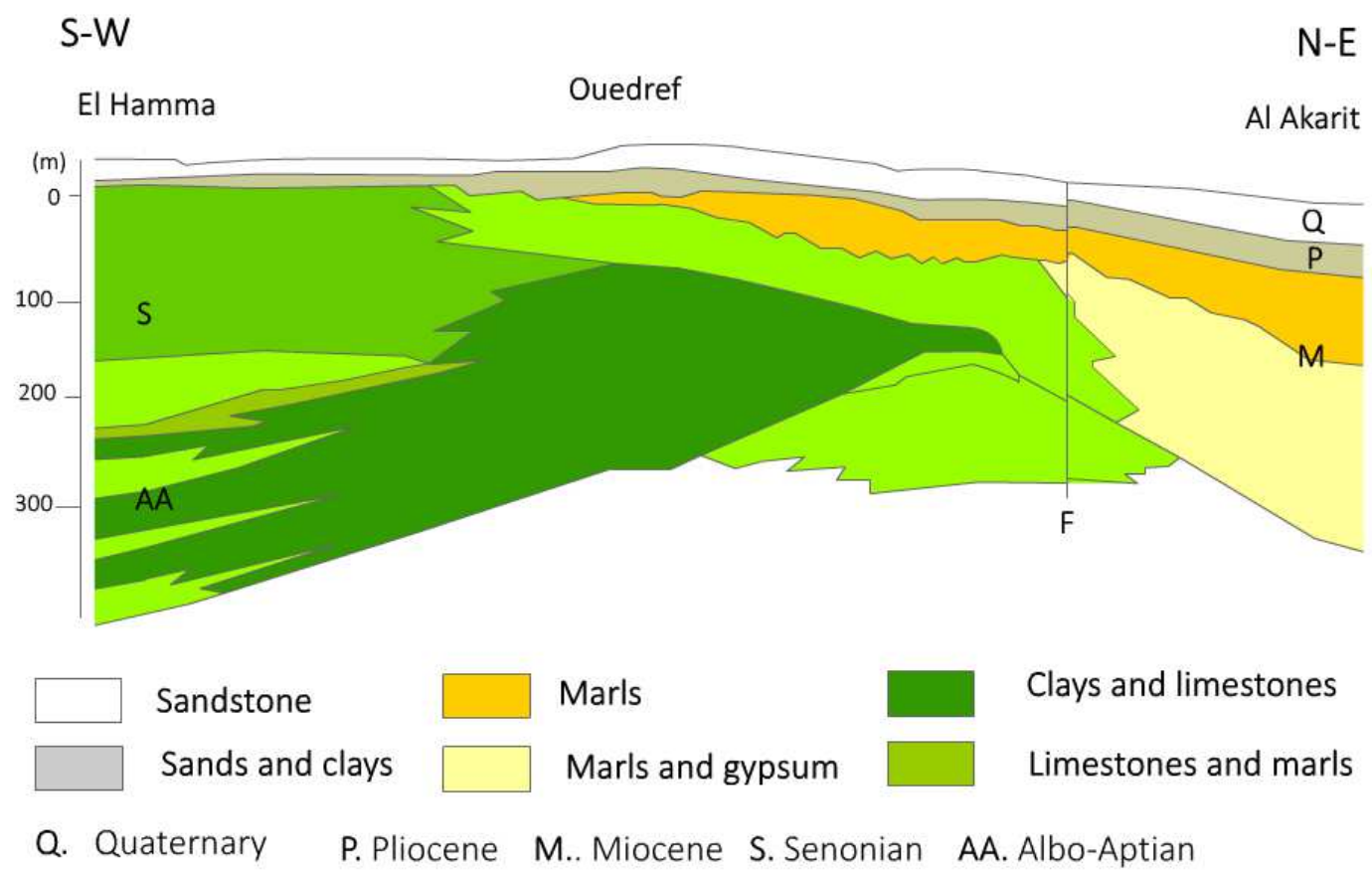

Fig. 2 Geological cross section (A-A') over study area (After Ben Hammouda et al. 2013, modified) 
Topography, lithology, geological features, groundwater depth, widespread cracks, primary porosity, secondary porosity, slope, drainage , land use and cover, and climate presented some of the variables that influence the presence and groundwater flow in a given region. Hydrogeology experiments and on-site geophysical studies help explain the groundwater recharge process and assess spatial-temporal differences in study regions (Abdollahi et al., 2015; .Malki et al. 2017).

As shown in figure 3, the methodology used in this study focused on groundwater potential recharge areas delineation using K-SOM method integrated remote sensing and GIS techniques. However, in order to delineate groundwater potential recharge areas, a database including geological, hydrogeological and topographic data was implemented. In this study, eight parameters were considered to assess groundwater potential areas: soil type, Land cover/use, slope, runoff, density of lineament, drainage density, lithology and geomorphology.

The lithological map was prepared by assembling, geo-referencing and digitizing local geological maps. The land-use and cover data were obtained through the Landsat 8 satellite images processing and then converted into raster format (30-m resolution).

The spatial pattern of the different factors estimated by K-SOM method will be presented with ArcGIS shown the lateral variations of the different parameters to identify regions in the study area where potential recharge zone may exist. 


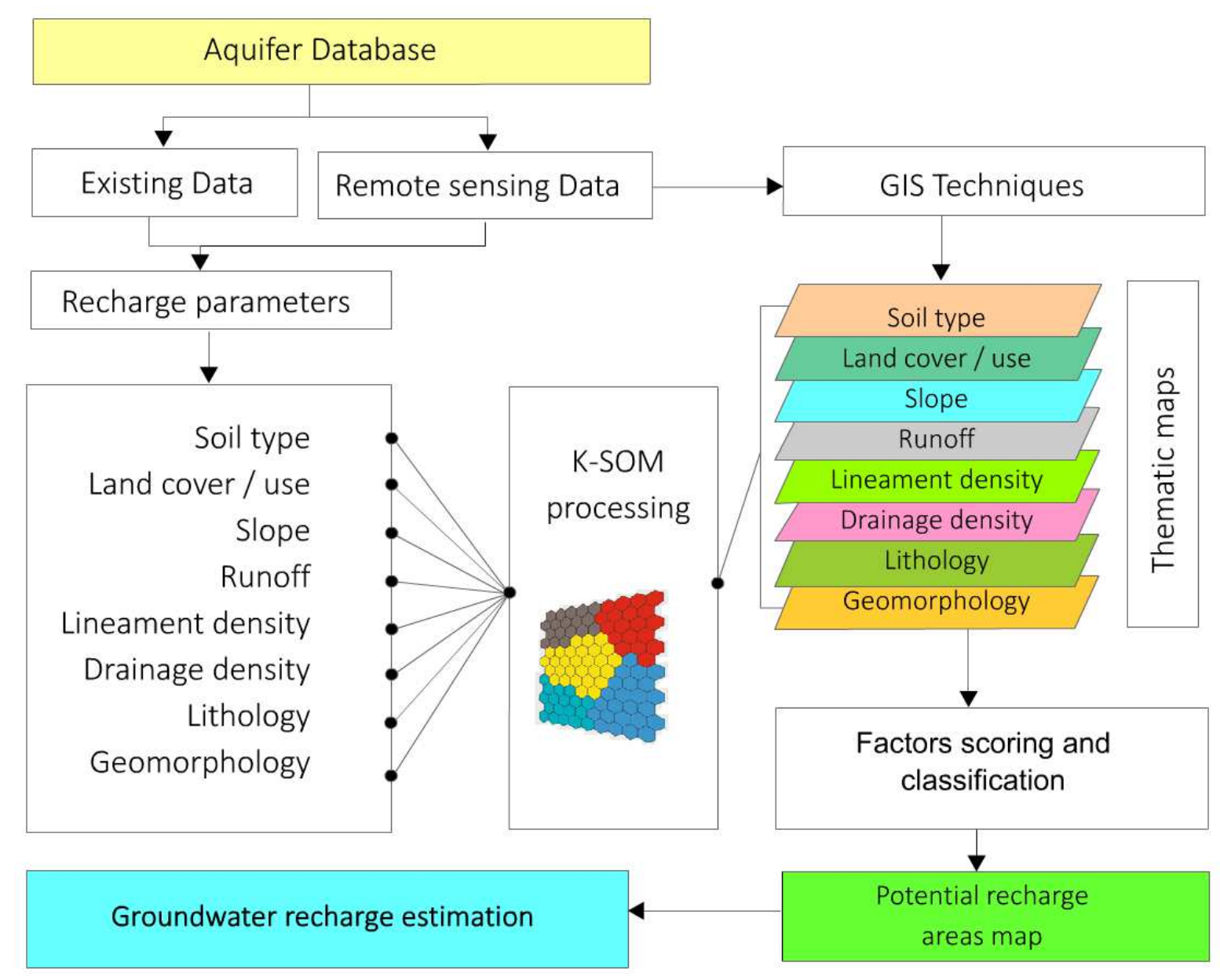

Fig. 3 Flowchart of groundwater potential index computation and mapping

\subsection{Parameters influencing groundwater recharge}

172 The main parameters influencing groundwater recharge were grouped in into three groups. The

173 first parameter groups is the physiographic parameters (slope, lineament density, 174 geomorphology, lithology); the second is the climatic parameters (runoff, drainage density) and the environmental parameters is the third group involved soil type and land cover-use. All the 176 parameters considered in this study as well as the role and influence of each parameter on 177 recharging will be detailed in what follows.

Soil type: The soil type parameter has an important influence on water infiltration. So, the soil

179 types will be grouped and classified into numerous classes on the basis of texture, thickness, 
drainage state, and water transmission capacity (Viessman et al., 1989). In recent literature, soil are classified into three classes such as Sandy and sandy silt, Sandy clay and silt, and Clay, sandy clay. For each soil class a weight will be assigned.

Land cover -use : This parameter is one of the most important factors infuencing and affect groundwater recharge. Land cover such as residential areas and vegetation cover controls the groundwater recharge. Leduc et al., (2001) indicated that groundwater recharge is affected by land utilization and vegetation cover. Thereby, land-use classes will be deciphered from Landsat 8 OLI/TIRS satellite images.

Slope : Groundwater recharge is affected by slope (Al Saud et al. 2010; El-Baz, 1995; Machiwal et al. 2011; Choi et al. 2012). Due to the substantial high accumulation of rainwater, low slopes promote groundwater recharge. The slope variance is assessed by the slope analysis function of GIS using data from the Tunisian digital terrain.

Runoff : Runoff is the unique source of water recharge in arid and semi- arid aeras. The runoff assessment depends on outcrop lithology in study area, which provides an important index of percolation (Trabelssi et al 2009). The runoff is estimated as follow [1]:

$$
\mathrm{R}=0.0164 \mathrm{P} \sqrt{\mathrm{I}_{\mathrm{g}}}
$$

Where, $\mathrm{R}$ is the runoff, $\mathrm{p}$ : is the mean of precipitation and ig is the slope.

Lineament density: Lineament density parameter is a critical in groundwater recharge assessment and delineation. Lineament (Faults, fractures, and discontinuity surfaces) provides the groundwater flow pathways (Abdalla 2012). The STRM dataset and geological map were used to produce lineament in the study area using the Geomatica 2015 platform. The density of lineaments is calculated as follows [2], in which Li is the length of each network portion and A is its surface.

$$
L_{d}=\frac{\sum_{1}^{n} L i}{A}
$$


Drainage density: Drainage network factor is an important parameter for groundwater recharge assessment. Thus, groundwater infiltration rate is more important in the highest runoff density region (Huang et al. 2013). Dainage network was generated from the topographic map using ArcHydro 10.8 software. This factor is computed as follows [3] where $\mathrm{Si}$ is the length of ith drainage network and $\mathrm{A}$ is the surface of studied area.

$$
D_{d}=\frac{\sum_{i=1}^{N} S_{i}}{A}
$$

Lithology: The lithology affects significantly water infiltration (El-Baz, 1995; Yeh et al. 2009;

Oikonomidis et al. 2015). The geological map 1:100000 of the study area will be used to assess the lithology variation.

Geomorphology: The geomorphology of the study area plays an important role in water distribution and availability and helps to identify potential groundwater recharge areas. Therefore, alluvial plain and low slopes help a great deal in groundwater infiltration due to their high porosity and permeability.

\subsection{Kohonen's self-organizing map analysis}

219 Kohonen's self-organizing map (K-SOM) is an unsupervised artificial neural network 220 (Cereghino and Park, 2009) designed by Kohonen (1982). Several authors such as (Cereghino and Park, 2009; Clark, 2018) describe K-SOM as an excellent technique for high-dimensional data visualization that decreases map dimensions ( 1 or 2$)$ by grouping related data items together. The self-organizing map presents one of the most prominent neural network models (Fig. 4). The K-SOM is an unsupervised learning machine and required a limited amount of

225 information as input data. It has the property of preserving topology data as well as the distance between them (Vesanto and Alhoneimi, 2000; Ousmana et al., 2016; Clark, 2018). 
Input layer

Kohonen Layers

Feature maps

(input vector)

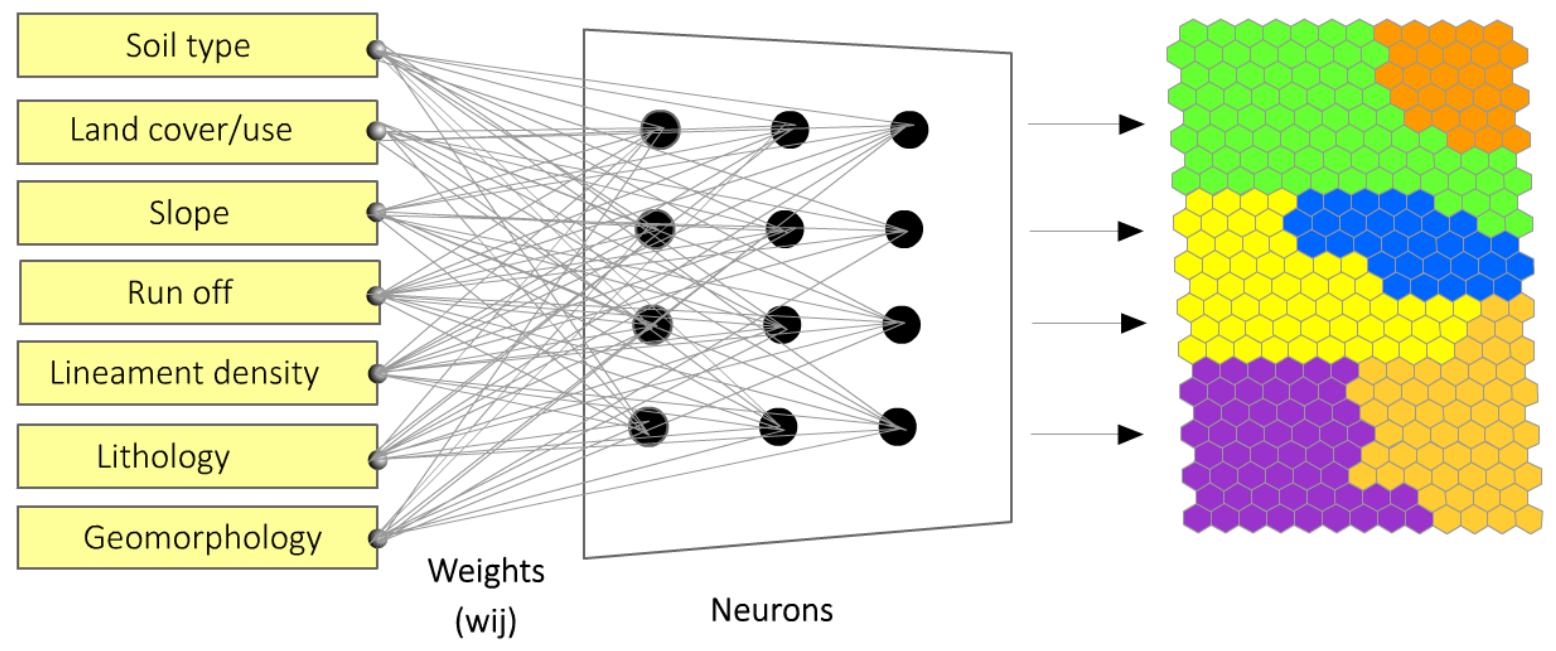

Fig. 4 Architecture of Kohoneen Self-organizing map neural network

The Kohonen self-organizing map algorithm uses the distance between the best-matching unit (BMU) and each data point to calculate error .The proportion of data using two BMUs that are not contiguous is calculated by K-SOM as topographic error (Kohonen 1982). In Kohonen maps, the neighborhood function hj(k,t) is a continuous Gaussian function (Fig. 5). The standard deviation is reduced, resulting in a reduction in the size of the neighborhood ( $\mathrm{t})$. The speed of learning is controlled by the learning step (x), whereas the convergence condition is based on standard deviation $(\mathrm{t}) . \varepsilon(\mathrm{x})$ and $\sigma(\mathrm{x})$ are calculated using the formulas [1] and [2], respectively.

$$
\begin{aligned}
& \varepsilon(\mathrm{x})=\varepsilon i\left(\frac{\varepsilon f}{\varepsilon i}\right)^{1 /(t \max )} \\
& \sigma(\mathrm{x})=\sigma i\left(\frac{\sigma f}{\sigma i}\right)^{1 /(t \max )}
\end{aligned}
$$

$$
\text { The topological error (Te) and quantization error (Qe) criteria are used to validate the SOM }
$$
classification. Te is a criterion for describing how the SOM maintains data topology. The data percent of the first two non-adjacent BMUs is measured. Qe is the distance between data and BMU (Kohonen 2001). Qe is computed as follow [3]: 
244 In which $\mathrm{N}$ is the number of dataset, $i$ is the $i^{\text {th }}$ individual, and $\mathrm{w}\left(\mathrm{x}^{\mathrm{i}}\right)$ is the best-matching unit 245 of the individual.

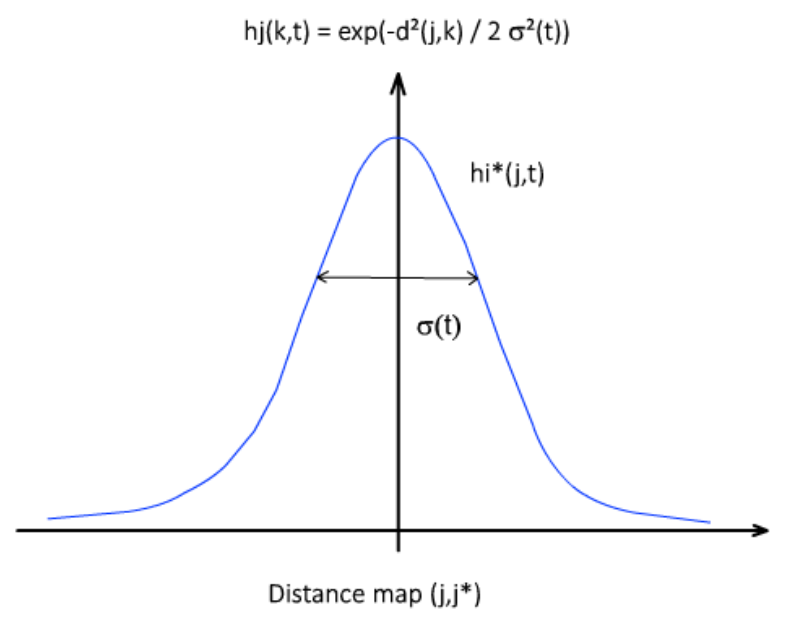

\subsection{Factor's and rating system}

249 The infiltration rate is used to assess factors governing groundwater potential recharge. The 250 chosen parameters were rated and a score from 1 to 10 is assigned for each parameter (Table 1). According to previous studies such as Yeh et al. (2016), Dar et al. (2020), factors namely slope, lithology, land use, land cover, drainage density, lineaments density, and runoff were rated from 1 to 8 in terms of their contribution to groundwater recharge. The fusion of these parameters is represented by the final potential recharge map of the study area. The integration of different factors and their causality links were taken into account while calculating the potential recharge used to estimate groundwater recharge as the factor weight is assessed using inter-parameter relationship effects (Fig. 6). 


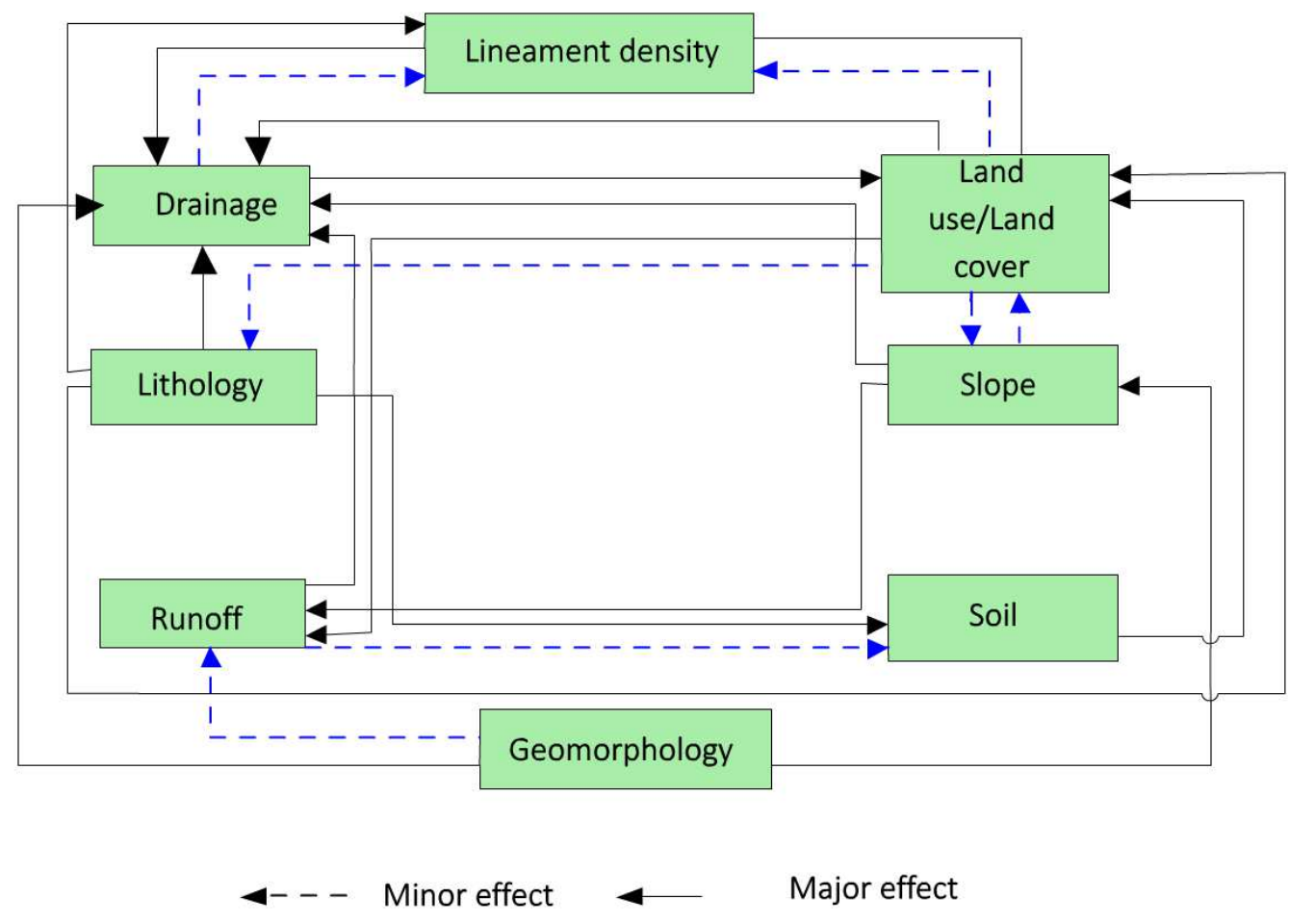

Fig. 6 Relations and effects inter-parameters controlling potential groundwater recharge (after, Singh et al. 2019)

261 The major effect is scored 1 and indicates a significant influence, whereas the weight 0.5 is

262 affected to the minor effect (Table 2), as follow [4]:

$$
\text { score }=\frac{(\text { Major effect }+ \text { Minor effect })}{\sum(\text { Major effect }+ \text { Minor effect })} * 100
$$


Table 1 weights and rates of factors used for assess groundwater potential recharge

\begin{tabular}{|c|c|c|c|c|c|c|}
\hline Recharge - factor & $\begin{array}{c}\text { Value ranges } \\
\text { (V) }\end{array}$ & $\begin{array}{l}\text { Weight } \\
\text { (w) }\end{array}$ & $\begin{array}{l}\text { Rates } \\
\text { (R) }\end{array}$ & $\begin{array}{c}\text { weighted } \\
\text { rating } \\
(\mathrm{w} . \mathrm{R})\end{array}$ & Sum & Classes \\
\hline \multirow{4}{*}{ Land cover - use } & Dry land & 8 & \multirow{4}{*}{2.5} & 20 & \multirow[t]{4}{*}{47.5} & Very good \\
\hline & Agriculture & 6 & & 15 & & Good \\
\hline & Bare land & 4 & & 10 & & Moderate \\
\hline & Urban zone & 1 & & 2.5 & & Poor \\
\hline \multirow{5}{*}{$\begin{array}{c}\text { Slope / } \\
\text { Topography }\end{array}$} & $<2^{\circ}$ & 6 & \multirow{5}{*}{2.5} & 15 & \multirow{5}{*}{47.5} & Very good \\
\hline & 2 tyo $4^{\circ}$ & 5 & & 12.5 & & Good \\
\hline & 4 to $10^{\circ}$ & 4 & & 10 & & Moderate \\
\hline & 10 to $15^{\circ}$ & 3 & & 7.5 & & Poor \\
\hline & $>15^{\circ}$ & 1 & & 2.5 & & $\begin{array}{c}\text { Extremely } \\
\text { Poor }\end{array}$ \\
\hline \multirow{5}{*}{ Aquifer lithology } & $\begin{array}{l}\text { Marl and } \\
\text { limestone }\end{array}$ & 1 & & 6 & & $\begin{array}{l}\text { Extremely } \\
\text { Poor }\end{array}$ \\
\hline & Silt and clay & 2 & & 8 & & Medium \\
\hline & Alluvium & 5 & & 20 & \multirow{3}{*}{88} & Good \\
\hline & $\begin{array}{l}\text { Sandy clay to } \\
\text { sand }\end{array}$ & 4 & \multirow[t]{2}{*}{4} & 16 & & Moderate \\
\hline & Sand & 6 & & 24 & & Very good \\
\hline \multirow{3}{*}{ Geomorphology } & $<110$ & 6 & \multirow{3}{*}{2} & 12 & \multirow{3}{*}{28} & Good \\
\hline & $110-660$ & 2 & & 4 & & Moderate \\
\hline & Rivers & 6 & & 12 & & Very good \\
\hline \multirow{4}{*}{ Drainage density } & $<1$ & 2 & \multirow{4}{*}{1.5} & 3 & & Low \\
\hline & 1 to 1.5 & 3 & & 4.5 & \multirow{3}{*}{22.5} & Moderate \\
\hline & 1.5 to 2.5 & 4 & & 6 & & Good \\
\hline & $>2.5$ & 6 & & 9 & & Excellent \\
\hline \multirow{3}{*}{ Soil type } & $\begin{array}{l}\text { Sandy and sandy } \\
\text { silt }\end{array}$ & 6 & \multirow{3}{*}{1} & 6 & & Good \\
\hline & $\begin{array}{c}\text { Sandy + clay and } \\
\text { silt }\end{array}$ & 2 & & 2 & 8 & Moderate \\
\hline & Clay, sandy clay & 0 & & 0 & & Poor \\
\hline \multirow{4}{*}{$\begin{array}{l}\text { Lineament density } \\
\qquad\left(\mathbf{k m} / \mathbf{k m}^{2}\right)\end{array}$} & $>1.5$ & 10 & \multirow[t]{4}{*}{2} & 20 & \multirow[t]{4}{*}{42} & Very good \\
\hline & $1-1.5$ & 6 & & 12 & & Good \\
\hline & $0.5-1$ & 4 & & 8 & & Moderate \\
\hline & $<0.5$ & 1 & & 2 & & Poor \\
\hline \multirow{5}{*}{ Runoff } & $<4 \%$ & 10 & \multirow{5}{*}{2.5} & 25 & \multirow{5}{*}{67.5} & Very good \\
\hline & $4-20 \%$ & 8 & & 20 & & Good \\
\hline & $20-35 \%$ & 5 & & 12.5 & & Moderate \\
\hline & $35-50 \%$ & 3 & & 7.5 & & Poor \\
\hline & $>50 \%$ & 1 & & 2.5 & & $\begin{array}{c}\text { Extremely } \\
\text { Poor }\end{array}$ \\
\hline
\end{tabular}


Table 2. Parameters assigned scores (after, Singh et al. 2019)

\begin{tabular}{lcclcc}
\hline Parameter & $\begin{array}{c}\text { Significant } \\
\text { effect }\end{array}$ & slight effect & $\begin{array}{l}\text { Rate } \\
\text { calculation }\end{array}$ & Rate & Score \\
\hline Lithology & 4 & 0 & $(4 \times 1)+(0 \times 0.5)$ & 4 & 19 \\
Lineament density $\left(\mathrm{km} / \mathrm{km}^{2}\right)$ & 2 & 0 & $2+(0 \times 0.5)$ & 2 & 10 \\
Geomorphology & 2 & 0 & $(2 \times 1)+(0 \times 0.5)$ & 2 & 10 \\
Slope & 2 & 1 & $(2 \times 1)+(1 \times 0.5)$ & 2.5 & 14 \\
Land cover & 1 & 3 & $(1 \times 1)+(3 \times 0.5)$ & 2.5 & 19 \\
Drainage density & 1 & 1 & $(1 \times 1)+(1 \times 0.5)$ & 1.5 & 10 \\
Runoff & 2 & 1 & $(2 \times 1)+(1 \times 0.5)$ & 2.5 & 14 \\
Soil & 1 & 0 & $(1 \times 1)+(0 \times 0.5)$ & 1 & 5 \\
\hline
\end{tabular}

\section{Results and discussion}

\section{Lithology}

271 Groundwater recharge is affected by lateral and vertical changes of strata. It has been pointed

272 out by several researchers (Yeh et al., 2009) that the lithology of the near surface formations

273 impact the potential recharge amount of groundwater resources. The physic-chemical proprieties of these deposits influence furthermore the recharge potential namely porosity and permeability (Oikonomidis et al. 2015, Welter.2018). This research includes rock variation that may alter lineages and morphology.

277 The Gabes district is overlain by alluvium and Quaternary sediments, which account for nearly $27870 \%$ of the absolute region, according to the lithology map (Fig. 7). In the study area, the 279 Lower Pleistocene and Pliocene are represented by sands and conglomerates which characterize by a moderate permeability and porosity important to the recharge phenomena. The Miocene is composed of coarse sand. Limestone marls and Cretaceous dolomite cover the

282 reliefs, that variability of lithology layers may can minimize the infiltration rate. The lithology parameter represents $25 \%$ of the potential recharge of the study area. 


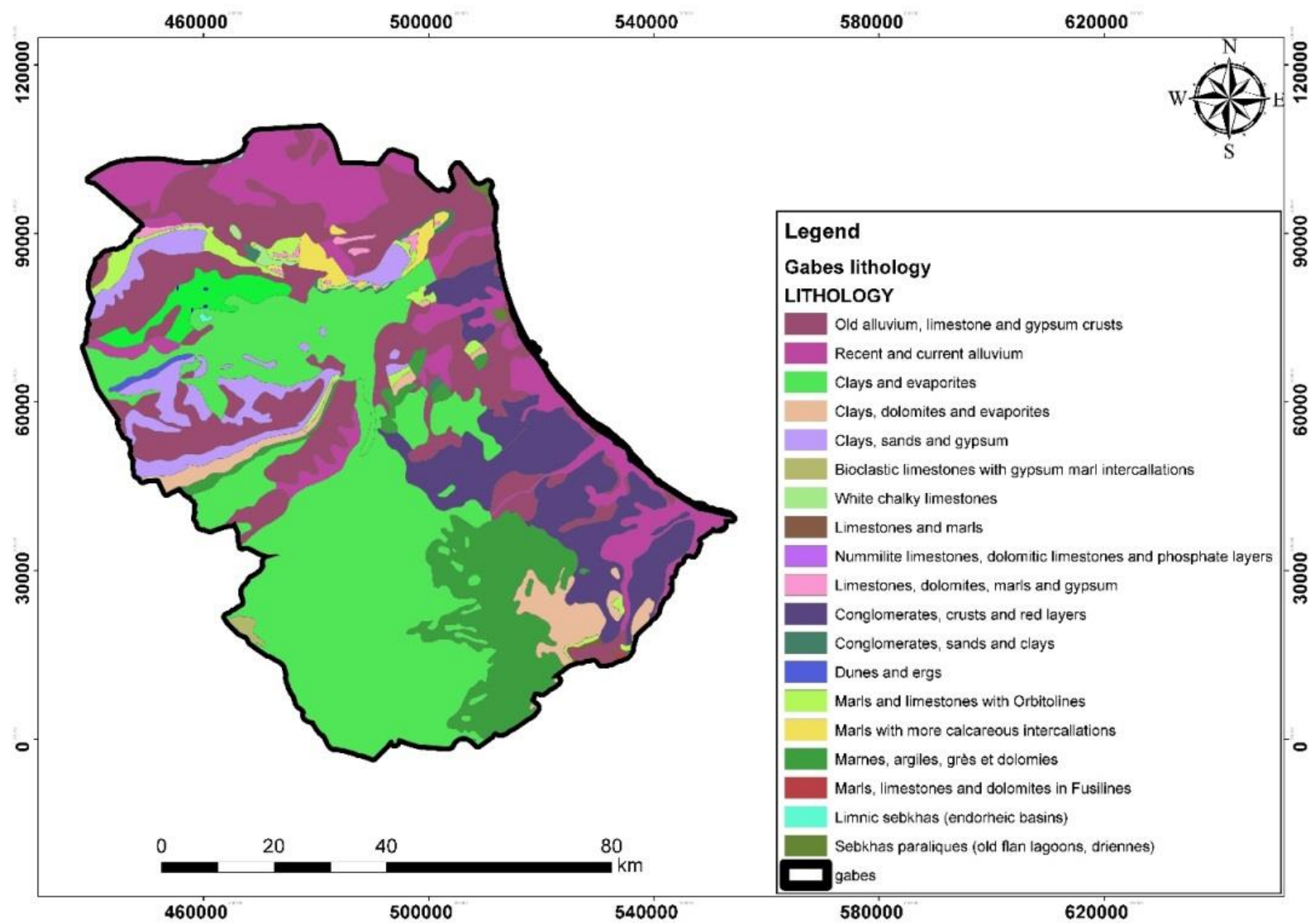

Fig.7: Lithology map of Gabes region (CRDA.2018)

\section{Geomorphology}

288 It is seen from figure 8 that plains and low landforms dominate the Gabes region's topography, with a relief ranging from 165 to 605 meters above sea level. Mountains and high landforms characterize the southern portion of the research region as well from the north. Based on the

291 geomorphology study, Gabes region show a plains in the mostly area in which the recharge 292 phenomena can have a good rate. Furthermore in a wide part of study area, these characteristics 293 may favorite the composition of wind deposits; floodplain deposits and salt evaporate deposits.

294 These variation in the geomorphology character proved a lateral contrast in the potential recharge area. 


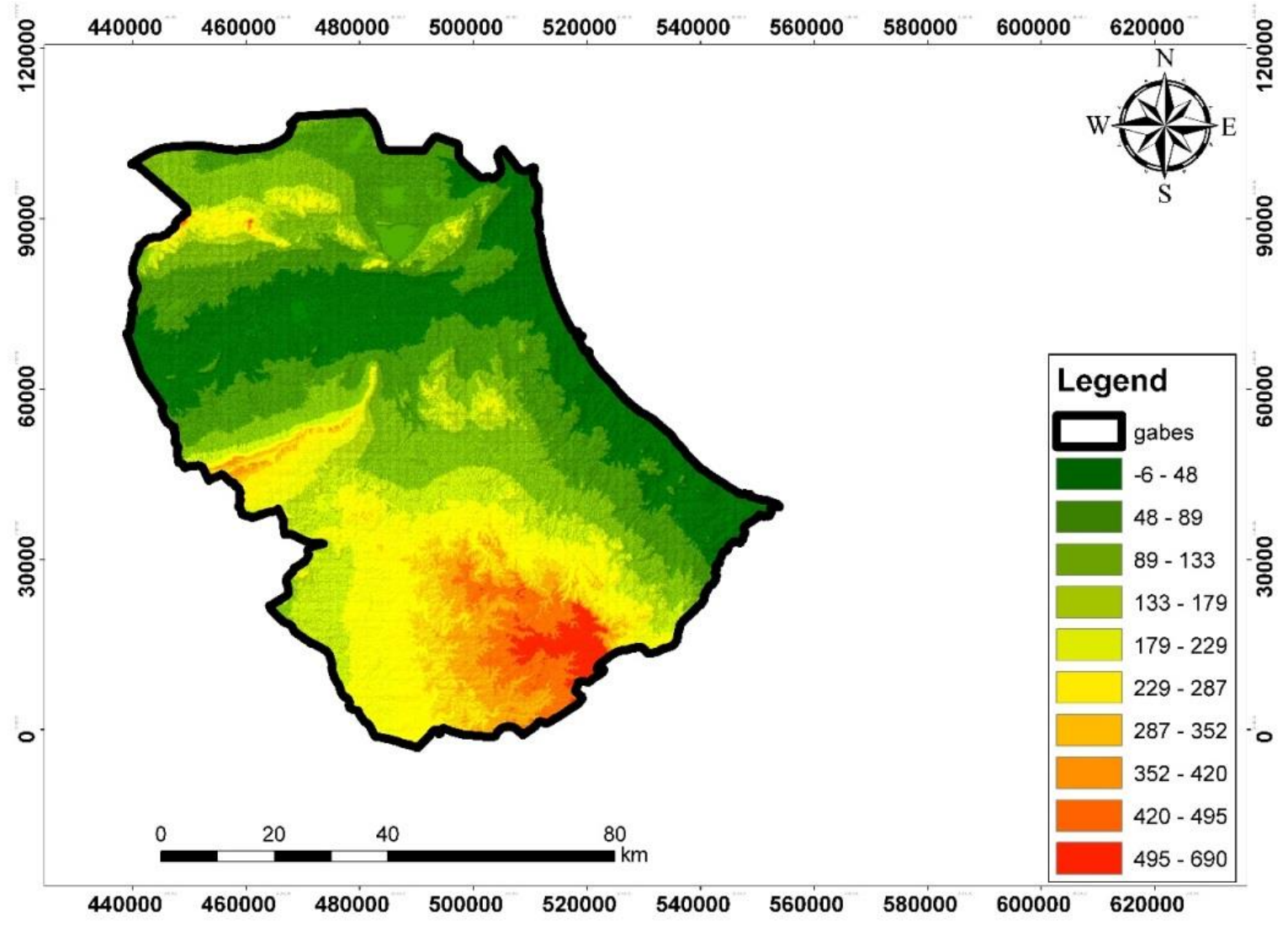

Fig. 8: Geomorphology map of study area

300 It is shown from Figure 9 that the study area present a different soil types. The most of the area 301 are covered by sandy-clay/sandy-silty soils, calcic soils and evaporitic. Thus, that variation 302 provide the physic characteristic of each type such as permeability and porosity (Ben Baccar 303 1982, Alaya et al. 2014) .based on those characteristic the recharge rate faces a very important 304 contrast all over the study region giving a point of view about the potential zone that can be managed. 


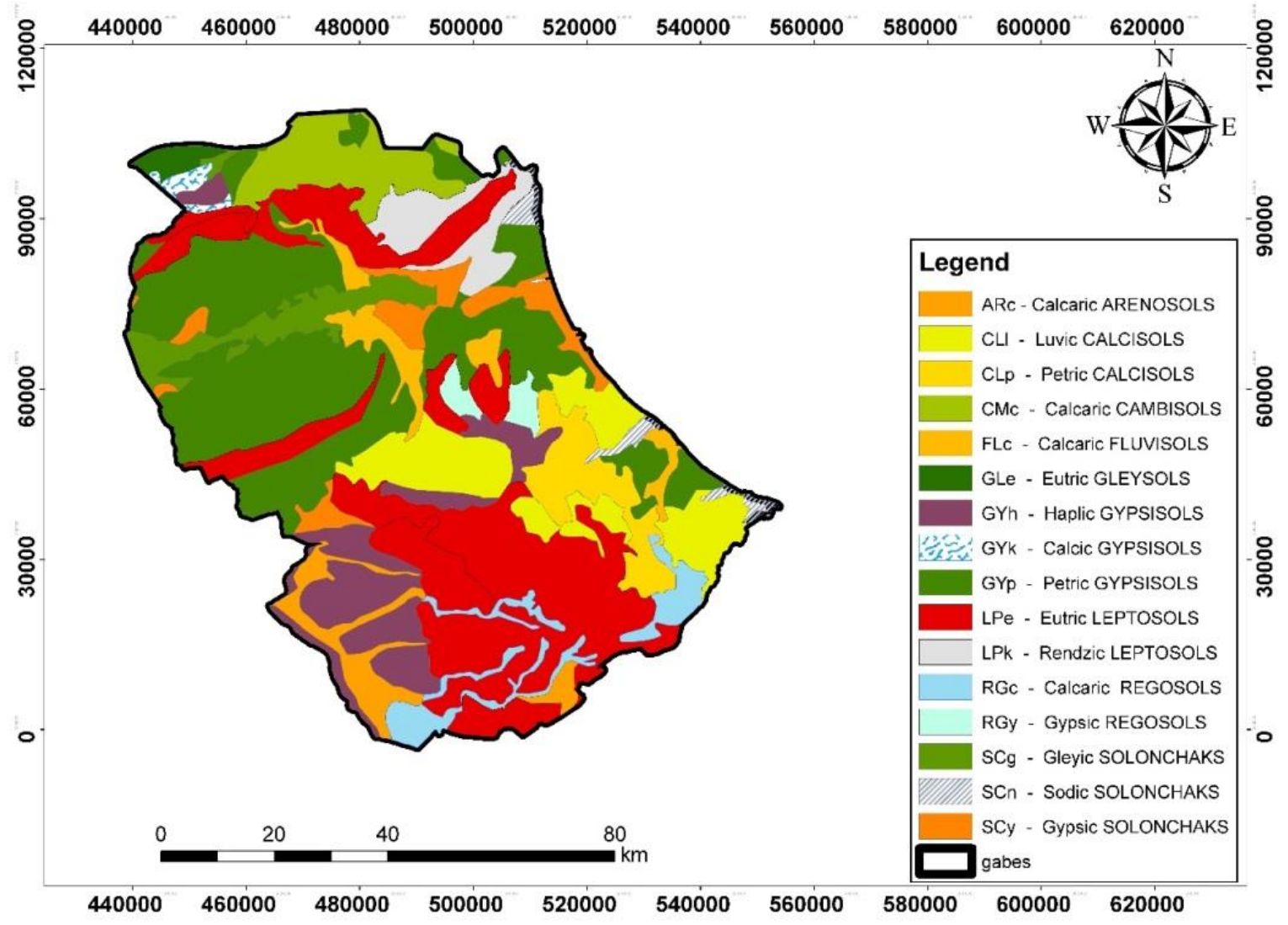

Fig. 9. Soil types map of the Gabes region

\section{Land cover}

313 Based on figure 10, the mostly of the study area is exposed land (more than $70 \%$ of the study area), where $10 \%$ of the region is covered by farming lands and sparse vegetation. That poverty of Greenland have a very important influence on the climate change in the region (Zheng et al 2019).the vegetation loss has many bad impact such as the raise of temperature degree. This later push the evapotranspiration rate minimizing the recharge phenomena. As presenting in the figure 8 that lateral variation of land cover can create a micro-climate like the oasis. Those characteristic influence the classification of potential recharge area (yeh et al 2009, Malki et al2017) 


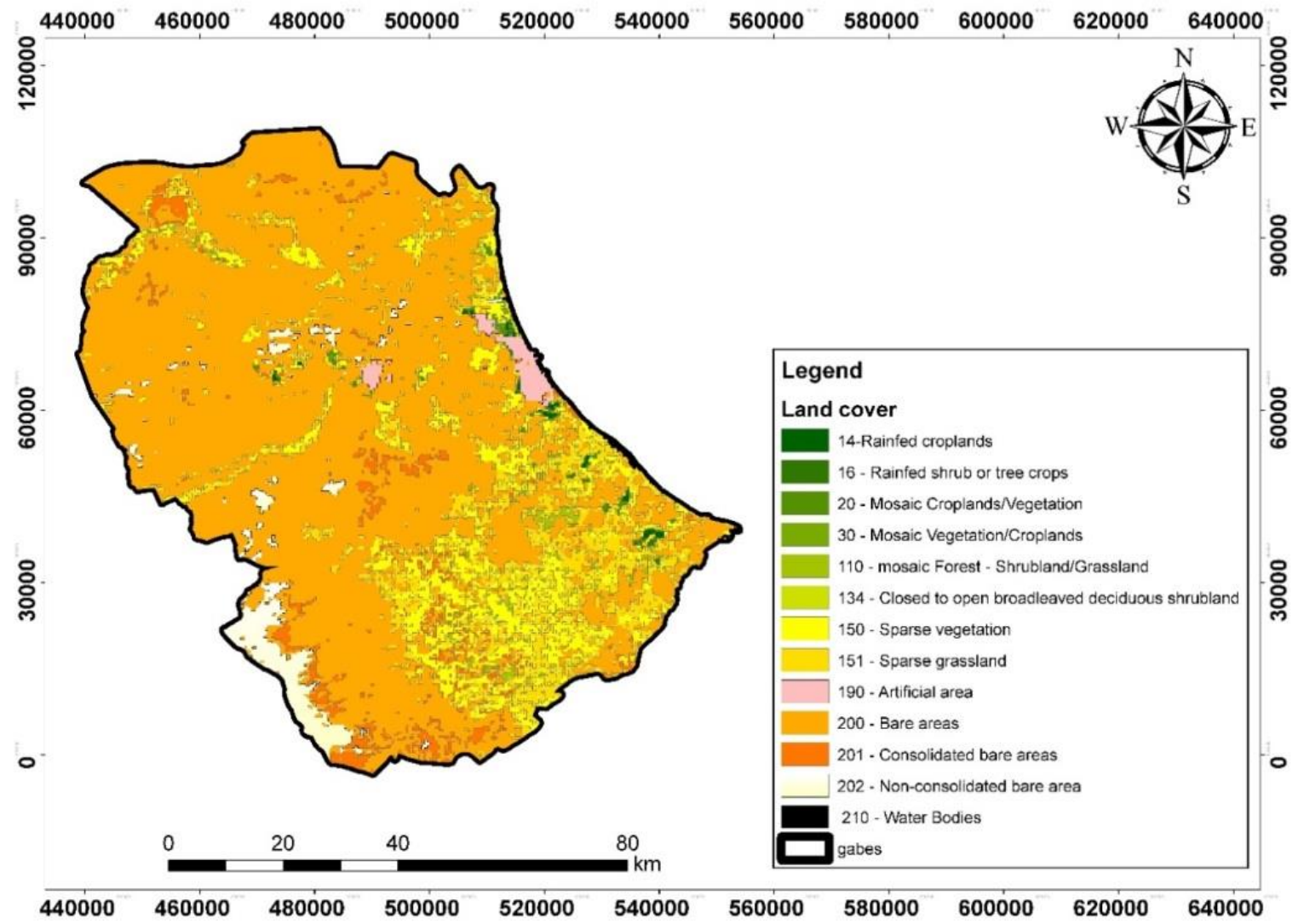

Fig. 10 Land cover of the Gabes region

\section{Drainage density}

325 The drainage network in Gabes region was detonated used the used the SRTM. The most

326 important flows are located in the south part of the stud region such as the Jir wadis, Segui

327 wadis and the Zigzaw wadis. In addition, we found as well the Akarit wadis and the Elhamma

328 wadis in the north part. Those wadis are decomposed in tow category endorhic (Elhamma

329 wadis) and exoreic (Zigzaw wadis). The density of drainage is varied between $\left[0-3.5 \mathrm{~km} / \mathrm{km}^{2}\right]$

330 .The Density where they are larger than $1.5 \mathrm{~km} / \mathrm{km} 2$, presented as a region with excellent

331 recharge zone those area present around $30 \%$ of the region. The evaluation of drainage density map is shown in Fig. 11. 


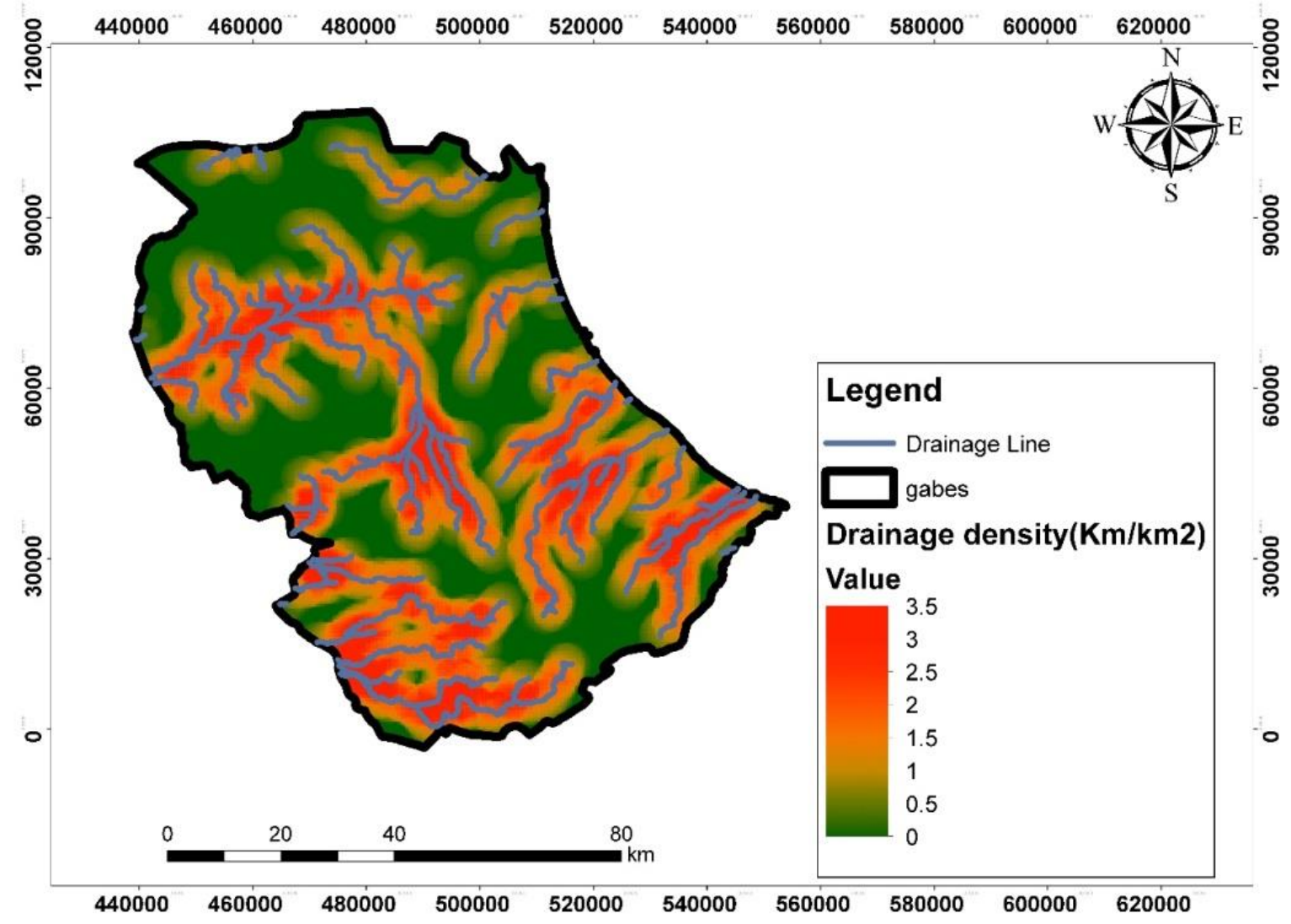

Fig. 11 Map of Gabes drainage density

\section{Analysis of lineament density}

In order the evaluation of the lineaments in Gabes region, the study based on the SRTM data an geological maps of the study region. The result was verified onsite and by bibliography

338 (Alaya et al 2014, Zouaghi 2011). The density map was obtained by ArcGIS10.8. The most important values is located in the north zone and in the mountainous area, may related the higher elevation of those area. More than 50\% from the cases study present a value, more than

$3411 \mathrm{~km} / \mathrm{km}^{2}$. The lineament density (Fig. 12) for the Gabes area indicates that the relief has a high

342 lineament density, with values varying from 1 to $1.8 \mathrm{~km} / \mathrm{km}^{2}$. The lineaments analyses presents

343 clearly demonstrate the superiority of a major NNW-SSE lineament course. This correlates to

344 the general position of deformation stress associated with the Miocene compressive tectonic

345 process (Zargouni 1985, Dlala 1995). 


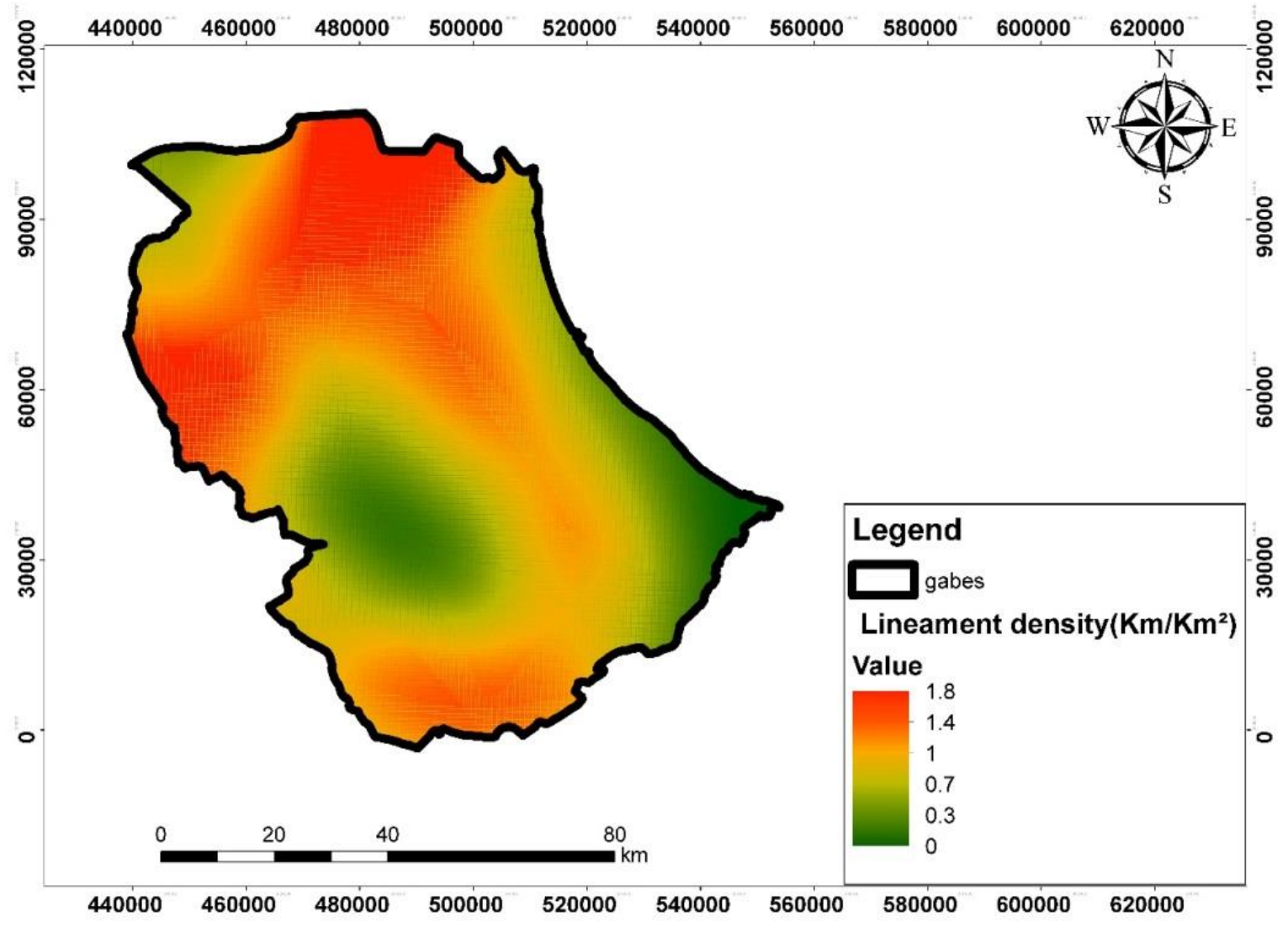

Fig. 12 Lineament density map of the study area

\section{Slope}

349 The assessment of the slope evolution in the study area was done based on the MNT treated

350 by GIS tools. As shown the generated maps (fig.13), the Gabes region was split into three

351 topographic levels based on the slope diagram. The first level (0-2) is assigned to very good class which my ameliorate the infiltration ( present the most of the study region ); the second

353 level (2-4) are rated as moderate groundwater recharge, while the third level is classified as

354 having an intensity of 4-10, suggesting a poor groundwater potential recharge. 


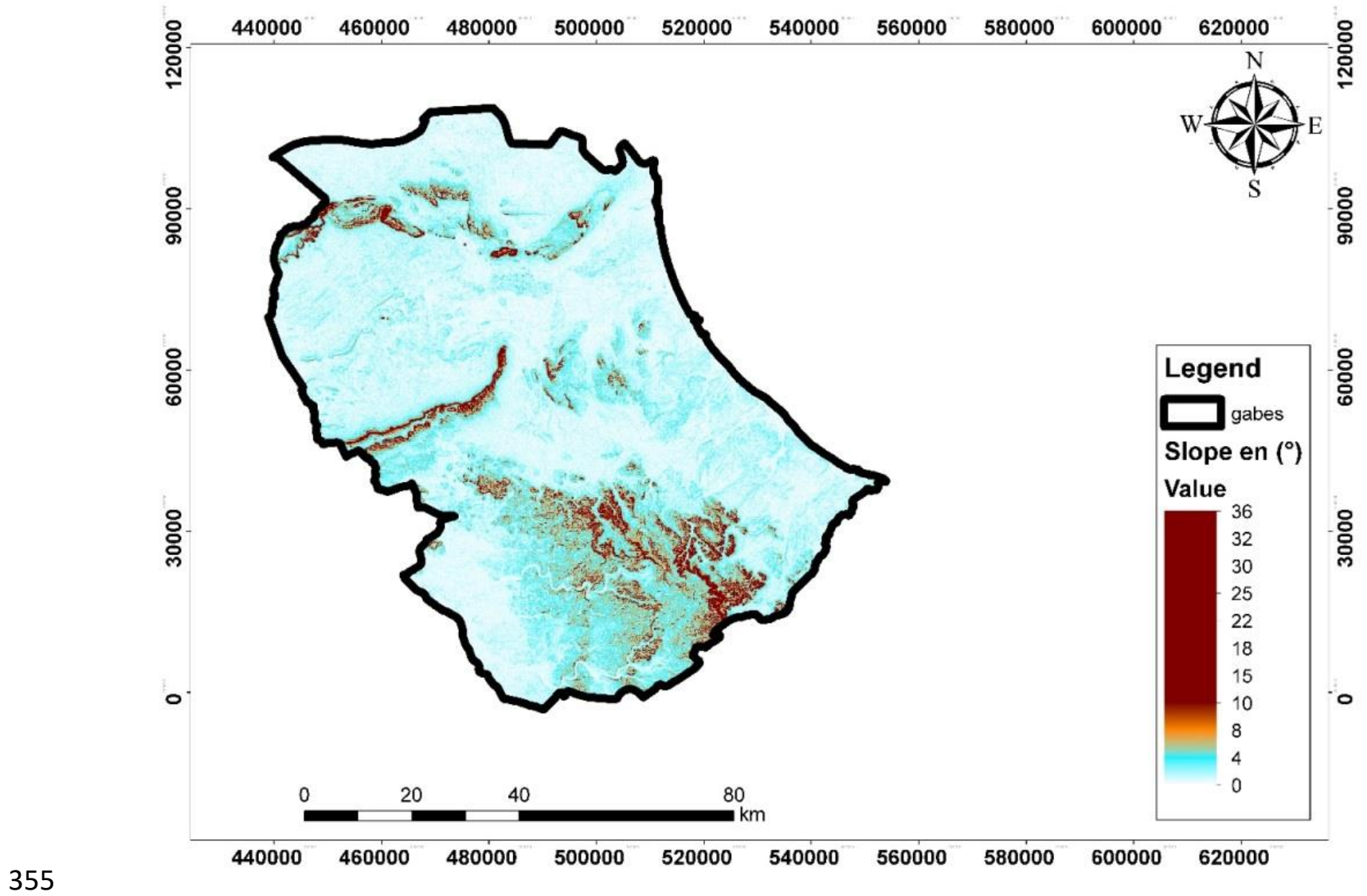

Fig.13 slope map of the study area

\section{Runoff}

358 The study area is categorized into five classes on the basis of runoff map (Fig. 14). Very good

359 groundwater potential recharge is assigned to the first class $(<4 \%)$. This class is located in flat

360 terrain; the second category (4-20\%), considered as good for groundwater recharge. The third

361 category (20-35\%), is a moderate recharge area. However, the rest of classes exceeding 35\%

362 and considered as poor potential groundwater recharge area. 


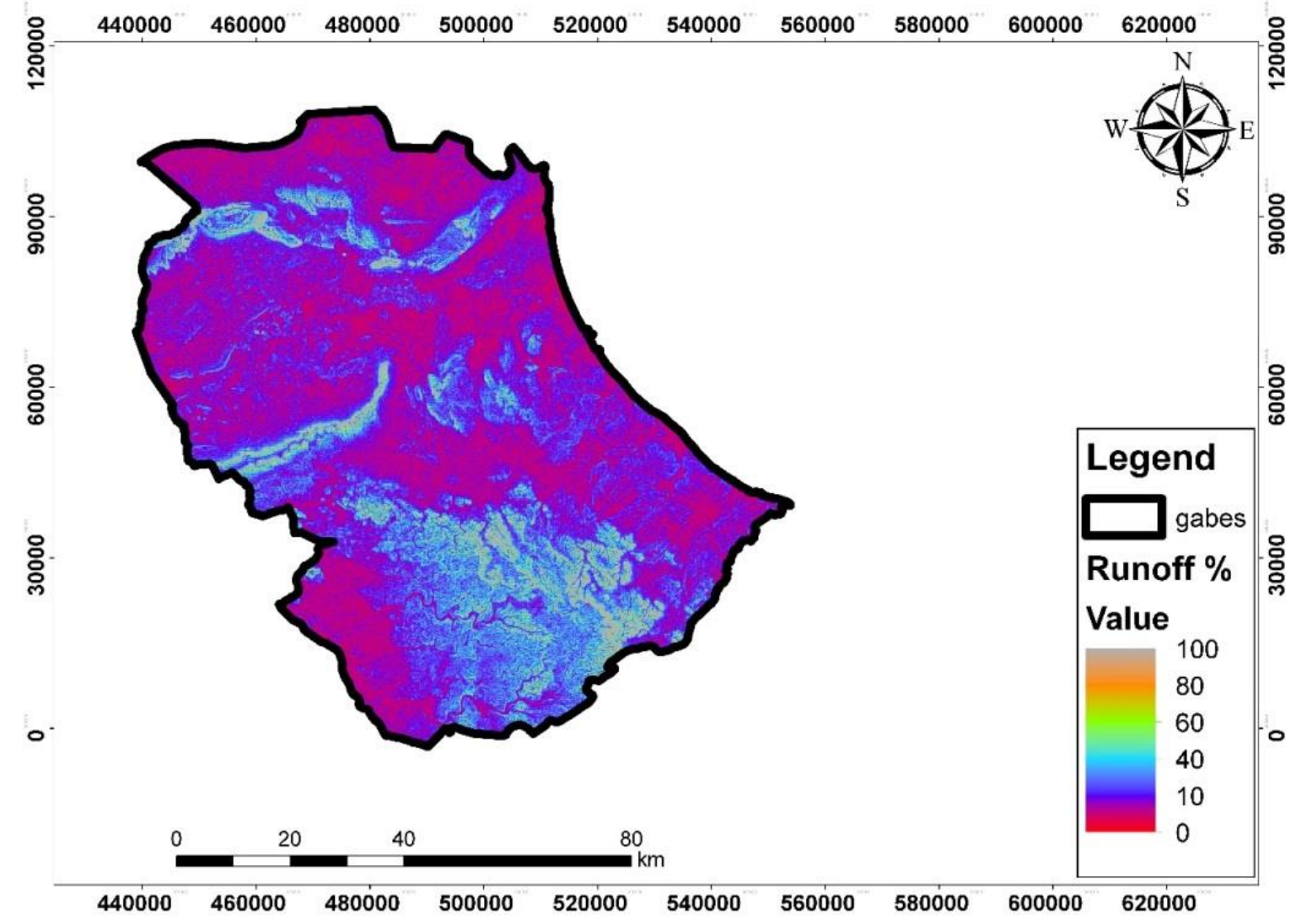

Fig. 14 Runoff map of the Gabes region

\section{Potential groundwater recharges areas assessment}

K-SOM has been performed using the various parameter that were indicated above from study area. Kohonen's self-organizing map was realized using SOM Matlab toolbox (Vesanto et al. 1999). Learning was realized until the quantization error after each time has been minimized. The KSOM quantification error (Fig.15a) shows that the error was stabilized in minimum values after 40 iterations. The k-SOM analysis results of clustered recharge data from the study area into five classes from very low to very good recharge potential zones. Those five classes were validated by the principal parameters analysis resulting of K-SOM (Fig. 15.b,c). 


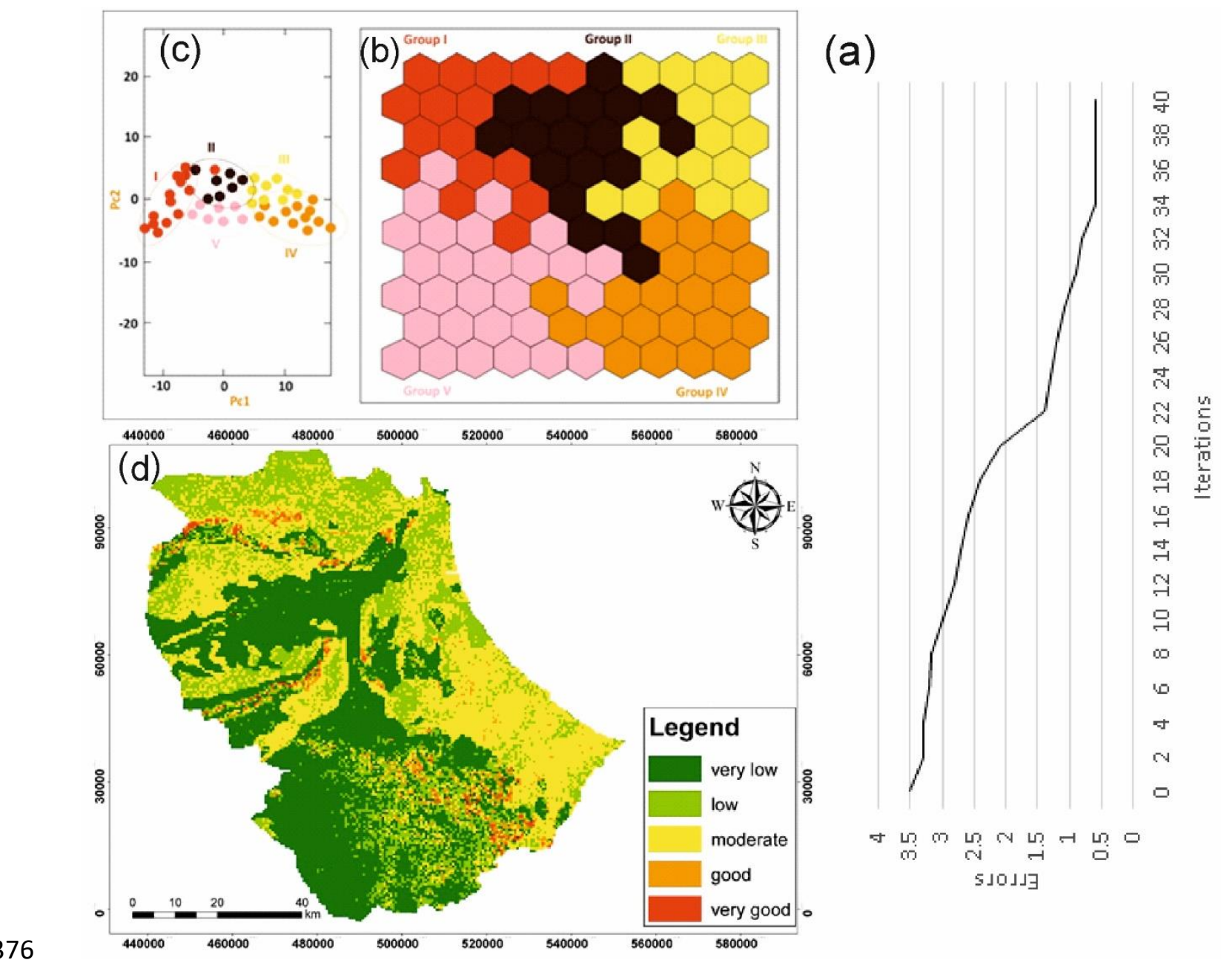

Fig. 15: K-SOM analysis results of potential groundwater zones in study area. (a) SOM quantification error after iteration, (b) Principal components, (c) K-SOM maps of obtained classes,(d) spatial distribution of groundwater potential zones in the study area

The five groundwater recharge classes were identified was presented as a map shown the lateral variation of those classes (fig.15, d). The first class is very low recharge and represents $27 \%$ of total surface of study area. The second is a low recharge area and occupies a $23 \%$ of study area, the third is about $40 \%$ of the surface and considered as moderate recharge, however the $7 \%$ is a good potential recharge and the fifth class has a very high potential recharge and represent only $3 \%$ of the total surface of study area. The hydrogeomorphological settings of study area reveal that the alluvial plain in the central basin has great groundwater potential to promote water infiltration characterized by lower slope, high permeability, and high infiltration rate. As 
for the mountainous and the hilly sites, located to the southern and western part of the study area, have limited potential recharge due to the low infiltration rate. The most important feeding area in the Gabes region is characterized by the interrelation of geological and geomorphological factors where the low slopes and the intrusion rate are very important, as well as the presence of ground cover that can enhance recharge rates, Whereas, the northern mountain chain is a faulted zone showing a very good potential recharge indicator.The most part of study area is a platform and coastal areas have a moderate recharge index due to the low lineament density and drainage as well as the influence of the land cover/use which has a bad impact on the groundwater recharge (table 3). The rest of the region presents the association of the same factors inducing a low and a very low potential groundwater recharge.

Table 3 Groundwater potential recharge estimation in the study area

\begin{tabular}{cccccc}
\hline Class & Very low & low & moderate & Good & Very good \\
\hline Area $\left(\mathrm{km}^{2}\right)$ & 1933.2 & 1648.18 & 2866 & 501.02 & 214.88 \\
Average $\%$ & 27 & 23 & 40 & 7 & 3 \\
$\begin{array}{c}\text { Potential recharge } \\
\left(\mathrm{m}^{3} \cdot \mathrm{y}^{-1}\right)\end{array}$ & 3093120 & 2637088 & 4585600 & 801632 & 343808 \\
$\begin{array}{c}\text { Total of recharge } \\
\left(\mathrm{m}^{3} \cdot \mathrm{y}^{-1}\right)\end{array}$ & & & & & \\
\hline
\end{tabular}

Quantifying groundwater recharge in southern Tunisia using hydrological and hydrodynamic models is a difficult task. Baba-Sy (2005) has indicated that infiltration rate varies between 2 and $10 \%$ in southern Tunisia. Consequently, infiltration is of 7 to $12 \mathrm{~mm} / \mathrm{year}$, which is estimated to 5 to $8 \%$ of annual precipitation. For potential groundwater recharge estimation in Gabès region, on the basis of Fersi (1979) findings, an infiltration rate of $8 \%$ from the annual precipitation of $200 \mathrm{~mm} \cdot \mathrm{y}^{-1}$, potential groundwater recharge is estimated to $11461248 \mathrm{~m}^{3} \cdot \mathrm{y}^{-1}$.

For a given hydrogeological system, the identification of the potential recharge zone using the RST can be used to translate several variables into one basic criterion to determine the proposal 
recharge zone. The RST provided as flexible approach fir adding or changing parameters. This method are using by several researches (yeh et al 2016, Yahyaoui et al 2021). Suissi et al 2018 was applied that method in same study region integrating a various parameters while reducing possibility of errors. Varaious are the study that based on the remote sensing technique but use of RST copulate with K-SOM method was so limited. In according with earlier studies (yeh et al 2016; Yahyaoui et al . 2017), the RST copulated with the self-organizing maps in this study used to evaluate the lateral variation of potential recharge zone in arid area specially in Gabes region . This method is robust and flexible with the criteria, as well it can be applied in many domain and in another study area .

\section{Conclusion and recommendation}

In this works, the recharge process was assessed to determine the potential recharge zone in Gabes region in order to purpose a required strategy to ameliorate the recharge phenomena, based on RST and K-SOM. This method used to define the weights of different criteria (slope, lithology, geomorphology, drainage, lineaments, land cover /user...). Groundwater potential zone is classed in five classes (very good, good, moderate, low and very low). The most part of the Gabes region are classed as moderate. The results confirmed that the Gabes region has a medium recharge potential, with $10 \%$ of the total area representing a high recharge while the rest of the region has a medium to very low recharge potential. The estimated potential groundwater recharge in Gabès region is of $11,46 \mathrm{Mm}^{3} / y e a r$. Additionally, a study of the impact of climate change on the amount and recharge process available in this region associate with an isotopies study would be a major aid to decision making at the local level.

\section{Declarations}

Conflict of interest the authors declare no competing interests. 
Foundation The authors declare that this work has no foundation support.

\section{References}

Abdallah, H., Memmi, L., Damotte, R., Rat, P., \& Magniez-Jannin, F. (1995). Le Crétacé de la chaine nord des Chotts (Tunisie du centre-Sud): biostratigraphie et comparaison avec les régions voisines. Cretaceous Research, 16(5), 487-538 (in French)

Abdollahi K. (2015). Basin scale water balance modeling for variable hydrological. African Earth Sciences, $132: 37-46$.

Agoubi B, (2021). A review: saltwater intrusion in North Africa's coastal areas - current state and future challenges. Environ Sciences Pollution Res. (28):17029-17043. https://doi.org/10.1007/s11356-021-12741-z

Agoubi B. (2018). Assessing hydrothermal groundwater flow path using Kohonen's SOM, geochemical data, and groundwater temperature cooling trend. Environmental Science and Pollution Research. https://doi.org/10.1007/s11356-018-1525-1

Agoubi B., Kharroubi A. et Abida H. (2012). Saltwater intrusion modelling in Jorf coastal aquifer, South-eastern Tunisia: Geochemical, geoelectrical and geostatistical application. Hydrol. Process journal. DOI: 10.1002/hyp.

Akbari, M., Alamdarlo, H. N., \& Mosavi, S. H. (2020). The effects of climate change and groundwater salinity on farmers' income risk. Ecological Indicators, 110, 105893.

Al Saud M. (2010). Mapping potential areas for groundwater storage in Wadi Aurnah Basin, western Arabian Peninsula, using remote sensing and geographic information system techniques. Hydrogeology journal, 18(6), 1481-1495.and Hydraulic Engineering, Vrije Universiteit Brussel, Brussels, Belgium, p 173. 
Arulbalaji P., D. Padmalal and K. Sreelash, (2019). AHP and GIS based delineation of groundwater potential areas. Scientific Reports (9):2082, https://doi.org/10.1038/s41598$\underline{019-38567-x}$

Awadh, S. M., Al-Mimar, H., \& Yaseen, Z. M. (2021). Groundwater availability and water demand sustainability over the upper mega aquifers of Arabian Peninsula and west region of Iraq. Environment, Development and Sustainability, 23(1), 1-21.

Baba-Sy J. (2005). Recharge of the aquifer system of the north Sahara. Published PhD thesis. University of Tunis.

Balamurugan G, Karthik S, Somnath B (2017). Frequency ratio model for groundwater potential mapping and its sustainable management in cold desert, India. J King Saud Univ - Sci 29(3):333-347

Ben Alaya M., S. Saidi, T. Zemni, F. Zargouni (2013). Deep-groundwater Assessment for drinking and irrigation use, Djeffara aquifers, Southeastern Tunisia. Env. Earth Sci (71):3387-3421. https://doi.org/10.1007/ s12665-013-2729-9

Ben Hamouda M.F., A. Mamou, J. Bejaoui, K. Froehlich (2013). Hydrochemical and Isotopic Study of Groundwater in the North Djeffara Aquifer, Gulf of Gabès, Southern Tunisia. International Journal of Geosciences, Vol. 4, No. 8A, p:1-10; DOI:10.4236/ijg.2013.48A001

Bouaziz S, Barrier E, Soussi M, Turki MM, Zouari H (2002) Tectonic evolution of the northern African margin in Tunisia from paleostress data and sedimentary record. Tectonophysics $357: 227-253$

Bouaziz S. (1995). Study of tectonics in the Saharan platform and Atlas (southern Tunisia): evolution of paleo-fields of constraints and geodynamic implications. $\mathrm{PhD}$ Thesis, University of Tunis. 
Bouderbala, A. (2019). The impact of climate change on groundwater resources in coastal aquifers: case of the alluvial aquifer of Mitidja in Algeria. Environmental Earth Sciences, 78(24), 1-13.

Cereghino R., Y. Park (2009). Review: the self-organizing map approach in water resources. Environ Model Software (24):945-947. https://doi.org/10.1016/j.envsoft.2009.01.008

Choi, W., Galasinski, U., Cho, S. J., \& Hwang, C. S. (2012). A spatiotemporal analysis of groundwater level changes in relation to urban growth and groundwater recharge potential for Waukesha County, Wisconsin. Geographical Analysis, 44(3), 219-234.

Clark S. (2018). Advance in SOM for spatiotemporal and nonlinear system. Doctorte of Philosophy, University of New South Wales, Sydney, Australia.190p (https://unsworks.unsw.edu.au/fapi/datastream/unsworks:52796/SOURCE02?view=true visited the August 9, 2021)

Dar T., N. Rai, A. Bhat (2020). Potential groundwater recharge zones delineation using AHP. Geology, and Landscapes :1-16. https://doi.org/10.1080/24749508. 2020.1726562

Dlala M., (1995). Evolution géodynamique et tectonique superposées en Tunisie : implication sur l'évolution géodynamique récente et la sismicité. Thèse En Sciences Géologique. Université de Tunis El Manar II

El Baz F., (1995). Groundwater potential recharge of the Sinai Peninsula in Egypt. Boston, Center for Remote Sensing.

Foster S., D.P. Loucks (2006). A guide-book on sustainable management of water policy makers. I.H.P Groundwater series, (10). Paris: UNESCO 
501 Freeze, R. and Cherry, J. (1979). Groundwater, Englewood Cliffs, New Jersey 07632. http://hydrogeologistswithoutborders.org/wordpress/1979-english/, accessed June 17, 2021)

Gude, V. G. (2018). Desalination of deep groundwater aquifers for freshwater suppliesChallenges and strategies. Groundwater for Sustainable Development, 6, 87-92.

Haridas V.R., S. Aravindan, G. Girish (1998). Remote sensing and applications for groundwater favorable areas identification. Quarterly Journal (6), 18-22.

Huang C., H.F. Yeh, H.I. Lin, S.T. Lee, K.C. Hsu, C.H. Lee (2013). Ground water recharge and exploitative potential zones using GIS and GOD. Envir. Earth Sci., (68): 267-280. doi:10.1007/s12665-012-1737-5

Kangur K, Park Y-S, Kangur A, Kangur P, Lek S (2007) Patterning longterm changes of fish community in large shallow Lake Peipsi. Ecol Model 203:34-44

Kohonen T. (1982) SOM formation of topological correct feature maps. Biol Cybern (43):5969

Kulmatov, R. A., Adilov, S. A., \& Khasanov, S. (2020, December). Evaluation of the spatial and temporal changes in groundwater level and mineralization in agricultural lands under climate change in the Syrdarya province, Uzbekistan. In IOP Conference Series: Earth and Environmental Science (Vol. 614, No. 1, p. 012149). IOP Publishing.

Kumar P.K., G. Gopinath, P. Seralathan P. (2007). Application of RS and GIS for delineation of groundwater potential zones: River basin in Kerala, southwest India. Intern. Jour. Remote Sensing (24), 5583-5601. Doi:10.1080/ 01431160601086050

L-Baz, F., et al., (1995). Groundwater potential of the Sinai Peninsula, Egypt. Project Summary. Boston, RS Center. 
Leduc C., Favreau G., Schroeter P. (2001). Long-term rise level in a Sahel watertable: The CT in south-west Niger. Journal of hydrology, 243(1-2), 43-54.

Lee GF, Jones-Lee A. (1999). Evaluation of surface water quality impacts of hazardous chemical sites. Remediation 9(2):87-113

Machiwal D., Jha M.K., Mal B.C (2011). Groundwater potential in a semi-arid region of india using RS, GIS and MCDM. Water resources management, 25 (5), pp:1359-1386.

Makni J, Ben Brahim F, Hassine S, Bouri S, Ben Dhia H (2012) Hydrogeological and mixing process of waters in deep aquifers in arid regions: south east Tunisia. Arab J Geosci 6:2673-2683. https://doi.org/10.1007/s12517-011-0510-5

Mamou A. (1990). Characteristics and Evaluation of water Resources in Southern Tunisia. PhD thesis, University of South-Paris, 425 p.

Melki A., Abdollah K., Fatahi R., and Abida H. (2017). Groundwater recharge estimation under semi-arid climate : Case of northern gafsa watershed, Tunisia. Journal of African Earth Sciences, Volume 132, 37-46, https://doi.org/10.1016/j.jafrearsci.2017.04.020

Mishra R.C., Biju C., Ranjitsingh D.N. (2010). Remote sensing and GIS for groundwater mapping and identification of artificial recharge sites. Geo Shanghai Inter. Conference: $216-223$

Nadiri, A. A., Norouzi, H., Khatibi, R., \& Gharekhani, M. (2019). Groundwater DRASTIC vulnerability mapping by unsupervised and supervised techniques using a modelling strategy in two levels. Journal of Hydrology, 574, 744-759.

Oikonomidis D. (2015). GIS and RS methodology for groundwater assessment in Tirnvos area, Greece. Journal of Hydrology (525):197-208. doi:10.1016/j.jhydrol.2015.03.056

Ousmana H, El Hmaidi A, Berrada M, Damnati B, Etebaai I (2016). Application of the self organizing map method for the classification of the environmental quality of the lake 
systems in the moroccan middle atlas: lakes cases of Ifrah, Iffer and Afourgagh. Larhyss Journal, ISSN 1112-3680, n²5, pp. 49-65

550

551

552

553

554

555

556

557

558

559

560

561

562

563

564

565

566

567

568

569

Parkinson, S., \& Hunt, J. (2020). Economic potential for rainfed agrivoltaics in groundwaterstressed regions. Environmental Science \& Technology Letters, 7(7), 525-531.

Pool, S., Francés, F., Garcia-Prats, A., Pulido-Velazquez, M., Sanchis-Ibor, C., Schirmer, M., ... \& Jiménez-Martínez, J. (2021). From flood to drip irrigation under climate change: Impacts on evapotranspiration and groundwater recharge in the Mediterranean region of Valencia (Spain). Earth's Future, 9(5), e2020EF001859.

Sahli H, Tagorti M A, Tlig S, (2013). Groundwater hydrochemistry and mass transfer in stratified aquifers ystem (Jeffara Gabes basin, Tunisia). Larhyss Jpurnal, 12, pp. 95-108.

Shrestha, S., Neupane, S., Mohanasundaram, S., \& Pandey, V. P. (2020). Mapping groundwater resiliency under climate change scenarios: A case study of Kathmandu Valley, Nepal. Environmental research, 183, 109149.

Singh S.K., M. Zeddies, U. Shankar, G.A. Griffiths(2019). Potential groundwater recharge zones in New Zealand. Geosci Front 10:1065-1072

Trabelsi, R. (2006). Approche itérative d'homogénéisation pour le comportement des composites polydisperses: applications à l'endommagement des mousses syntactiques immergées (Doctoral dissertation, Paris 6).

UNESCO (2019). The United Nations World Water Development Report. Executive Summary, 15p. (https://unesdoc.unesco.org/ark:/48223/pf0000367303, visited the June 15, 2021)

Vesanto J., E. Alhoneim E, (2000). Clustering of the S.O.M., IEEE Trans Neural Networks, 11: $586-600$ 
Walter, J. (2018). Modèle d'évolution naturelle de l'eau souterraine dans une région du Bouclier Canadien à partir de la détermination de pôles hydrogéochimiques régionaux (Doctoral dissertation, Université du Québec à Chicoutimi).

Yahiaoui B., B. Agoubi, A. Kharroubi (2021). Groundwater potential recharge areas delineation using GPRI index: Ghomrassen, south Tunisia. AJGS journal,14:919 ; https://doi.org/10.1007/s12517-021-07173-5

Zargouni F (1985) Tectonique de l'Atlas Méridional de Tunisie: évolution géométrique et cinématique des structures en zone de cisaillement. Rev Sci Terre 3:304p

Zargouni, F., 1985. Tectonics of the Southern Atlas of Tunisia. Geometric and kinematic evolution of structures in shear zones. Thesis in Sciences. Louis Pasteur University, Strasbourg, France, 296 (In French).

Zheng, K., Wei, J. Z., Pei, J. Y., Cheng, H., Zhang, X. L., Huang, F. Q., ... \& Ye, J. S. (2019). Impacts of climate change and human activities on grassland vegetation variation in the Chinese Loess Plateau. Science of the Total Environment, 660, 236-244.

Zouaghi T, Guellala R, Lazzez M, Bédir M, Ben Youssef M, Inoubli MH, Zargouni F (2011) The chotts fold belt of southern Tunisia, North Afrian margin, structural pattern, evolution and regional geodynamic implications. In: Schattner U (ed) New frontiers in tectonic research —At the midst of plate convergence. InTech. ISBN 978-953-307-594-5 